University of Wollongong

Research Online

Faculty of Law, Humanities and the Arts Papers (Archive)

Faculty of Arts, Social Sciences \& Humanities

$1-1-2014$

Shaming and sanitation in Indonesia: A return to colonial public health practices?

Susan Engel

University of Wollongong, sengel@uow.edu.au

Anggun Susilo

University of Brawijaya

Follow this and additional works at: https://ro.uow.edu.au/lhapapers

Part of the Arts and Humanities Commons, and the Law Commons

Research Online is the open access institutional repository for the University of Wollongong. For further information contact the UOW Library: research-pubs@uow.edu.au 


\title{
Shaming and sanitation in Indonesia: A return to colonial public health practices?
}

\begin{abstract}
Adequate sanitation is vital to human health, yet progress on the Millennium Development Goal for sanitation has been slow and the target is likely to be missed by one billion people. Indonesia has the third highest number of people of any country in the world without access to sanitation and, like most developing countries, it is devoting insufficient resources to the issue. In rural areas, rather than providing additional funding, the government - with support of the World Bank - has promoted the Community-Led Total Sanitation (CLTS) approach, which uses social mobilization to encourage people to construct their own latrines. In Indonesia as elsewhere, CLTS involves more than just education and encouragement; it uses social shaming and punishments. The authors argue that this is not only an inadequate approach but one which echoes coercive, race-based colonial public health practices. This article thus integrates extant historiography on Indonesian colonial medicine with contemporary scholarly literature and field research on CLTS using case studies of a 1920s hookworm-eradication programme funded by the Rockefeller Foundation, and the current World Bank Water and Sanitation Programme, both in Java.
\end{abstract}

\section{Keywords}

colonial, return, indonesia, sanitation, public, shaming, practices, health

Disciplines

Arts and Humanities | Law

\section{Publication Details}

Engel, S. \& Susilo, A. (2014). Shaming and sanitation in Indonesia: A return to colonial public health practices?. Development and Change, 45 (1), 157-178. 


\title{
Shaming and Sanitation in Indonesia - a return to colonial public health practices?
}

Susan Engel (University of Wollongong, email: sengel@uow.edu.au) and Anggun Susilo (University of Brawijaya, email: angbos@gmail.com)

A later version of this article appears in Development \& Change 45(1) 2014: 157-178

\begin{abstract}
Adequate sanitation is vital to human health, yet progress on the Millennium Development Goal for sanitation has been slow and the target is likely to be missed by one billion people. Indonesia has the third highest number of people of any country in the world without access to sanitation and, like most developing countries, it is devoting insufficient resources to the issue. In rural areas, rather than focusing additional funding, the Government with support of the World Bank, has promoted the Community-Led Total Sanitation (CLTS) approach, which uses social mobilisation to encourage people to construct their own latrines. In Indonesia as elsewhere, CLTS involves more than just education and encouragement, it uses social shaming and punishments. We argue that this is not only an inadequate approach but one which echoes coercive, race-based colonial public health practices. Thus our paper integrates extant historiography on Indonesian colonial medicine with contemporary scholarly literature and field research on CLTS using case studies of a 1920s Rockefeller Foundation funded hookworm eradication program and the World Bank's Water and Sanitation Program, both in Java.
\end{abstract}

\section{Acknowledgements}

We would like to thank M. Ilham Sofyana for sharing his insights and analysis during our fieldwork. Two anonymous referees provided thorough and constructive comments that significantly improved the final version of this article; a big thanks for their input. Thanks also to Ian Rosier for his editorial and fieldwork support. Finally, we wish to acknowledge the villagers who sacrificed their time for the interviews. 


\section{INTRODUCTION}

Improving sanitation is an important goal - some 2.4 billion people across the globe lack access to improved sanitation and that increases their vulnerability to disease because human waste transmits bacteria, viruses and parasites that harm human health (WaterAid n.d.). The health impacts on children are particularly dire as diarrhoea is the second biggest killer of children under five worldwide, while for girls and women lack of sanitation impacts school attendance especially during menstruation and it impacts safety, as women often wait for the cover of dark to open defecate. Poor sanitation impacts productivity, longevity and health care costs for the whole community. Untreated or poorly treated sewerage is also a major source of water and environmental contamination.

We set out to study a sanitation project in East Java, Indonesia, with a particular focus on the district of Trenggalek. Our initial concern was issues of decentralisation and participation in the post-reform context, however, we quickly became concerned about the use of shaming techniques to promote improved sanitation and to end open defecation. Programs to promote sanitation have been in place since colonial times. The technique of inducing shame and embarrassment amongst the community about open defecation that is now popular evolved from social mobilisation approaches to community development and was labelled Community-Led Total Sanitation (CLTS). It was developed in 1999 in Bangladesh by Kamal Kar, who was working with local and international non-governmental organisations (Harvey 2011: 96). ${ }^{1}$ CLTS is now a widespread and commonly used approach in rural and peri-urban sanitation and is promoted as a way to aid achievement of the Millennium Development Goal (MDG) on sanitation, where progress has been slow. The technique was originally promoted by non-governmental organisations (NGOs) and some developing country governments have adopted it, but its rapid spread is predominately due to the support of major donors, in particular the World Bank. CLTS is, for example, the key technique in the sanitation component of the multi-donor funded and World Bank-led, Water and Sanitation Program (WSP), which operates in 25 countries (WSP 2011).

The CLTS is a supposedly participatory process with two main stages. In the first stage communities are taken through a 'walk of shame' to identify and raise consciousness regarding the extent of faecal matter in the village; they then participate in a defecation mapping exercise which is supported by technical data in the form of core faecal counts. The second stage is household latrine

\footnotetext{
${ }^{1}$ It was pioneered in the small community of Rajshahi, Bangladesh by Kamal Kar who was working with a local non-governmental organisation, the Village Education Resource Centre (VERC) with support from Water Aid (Kar and Pasteur 2005: 1). The approach was then adopted by other NGOs before becoming mainstream among bilateral and multilateral donors such as the World Bank.
} 
construction, backed by technical advice and further action with those unable or unwilling to construct latrines but not by financial support from the state. While some proponents posit that the triggering process is not supposed to 'shame, insult or embarrass the community in any way' (Harvey 2011: 100) and others note that it is about collective consciousness-raising of the severe impacts of open defecation (Kar and Pasteur 2005), the reality is that in a range of countries using the technique, it involves system of 'fines, taunting or social sanctions to punish those who continue to defecate in the open'(Pattanayak, Yang et al. 2009: 581, emphasis added). Viewing the project on the ground, we were quite surprised by the CLTS approach and its inclusion under the umbrella of participatory development and even more surprised to find that there have, as yet, been few studies critical of the approach. The supportive studies and evaluations we found were produced or funded by donors promoting the technique.

The support for shaming is based on its supposed effectiveness in achieving latrine construction, which was also a key argument for the often coercive approaches used in colonial public health programs in Indonesia and elsewhere. Our paper does not aim to fully evaluate the effectiveness or otherwise of shaming versus other techniques for promoting sanitation, rather it seeks to integrate the extant historiography of Indonesian colonial medicine with contemporary scholarly literature and our own field research on CLTS using case studies of the 1920s Rockefeller Foundation funded hygiene and sanitation program and the WSP program in East Java in the 2000s. This enables us to highlight new insights about the outcomes of CLTS as a hybrid approach that links colonial and modern governmentality but, in its modern form, involves not just the state but also sub- and supranational organisations of various kinds. Foucault's idea of government as the 'conduct of conduct' incorporating 'governing the self' and 'governing the other'(Foucault 1991: 87; Lemke 2002) is useful a way of highlighting some of the connections between the WSP and Rockefeller programs. Both of these projects are about educating desires, habits, aspirations and beliefs; they are a form of government through (constructed) community (Li 2007). They both involve what Li (2007) calls 'rendering technical', which highlights the process by which a particular 'problem' is identified, its boundaries set, legitimate information is collected and appropriate techniques for addressing the 'problem' are crafted. Both programs also highlight the continuities of governmentality with older coercive regimes which are linked, in the Rockefeller case, to colonial racial stereotyping and, in the WSP case, to class stratification. The result is a form of governmentality that does not engage with local practices in their cultural, ecological social, political and economic dimensions (Jewitt 2011). F When villagers resist donor sanitation programs, it is understood as a continuation of a 'filthy', traditional practices and not engaged with as an ethico-political (Mukhopadhyay 2006) and/or socio-economic response. The content and nature of the program are never questioned. Thus, in looking at WSP in the context of historical interventions in sanitation in Indonesia and elsewhere, 
we shed new light on modern sanitation regimes for rural areas and their claims of participatory development.

In this paper, we start by examining colonial hygiene and public health practices in Indonesia, which highlights a number of interesting continuities between colonial developmental regimes and current aid practices. Next we evaluate the WSP sanitation project in East Java and in Trenggalek in the light of both colonial health practices and post-World War II sanitation practices by donors and concluding with an analysis of WSP as participatory development.

\section{SHAMING AND COLONIAL SANITATION PRACTICES IN INDONESIA}

Sanitation was one of the earliest arenas of colonial public health activity in the Dutch East Indies thanks to the appointment of sanitary inspectors. Intervention grew with the expansion of Dutch control over the peninsula and the introduction of the so-called Ethical Policy in 1901, which increased the focus on 'native’ welfare (Boomgaard 1993; Furnivall 1967: 362-3; Mesters 1991; Mesters 1996). This change coincided with the major breakthroughs in medical science that marked the start of modern medicine, which in turn provoked significant changes in colonial health practices (Anderson 2006; Comaroff and Comaroff 1997; Hattori 2004; Latour 1988). The substantial Rockefeller Foundation-funded hookworm eradication program commenced in 1924 and focused more on preventative public health than on treatment, in other words on hygiene and sanitation improvements to stop hookworm spread. The focus on preventative public health programs was seen as an affordable way of providing modern scientific health knowledge to the masses, in contrast to expensive biomedical interventions which only reached a few. The program encouraged a move away from the traditional Dutch approach of legislating for latrine construction, backed-up by fines, towards an approach that focused on hygienic practices utilising social mobilisation and education techniques; despite its racial overtones, it was very much a program of conducting conduct (Amrith 2006: 30). There is a parallel here to the change that occurred in development practice in the 1990s, whereby the sanitation sector changed from focusing on the provision of hardware to focusing on participation and social mobilisation in order to encourage individuals and communities to construct and maintain their own sanitation facilities. We return to this change later in the paper.

The use of both coercive and educative techniques in public health was not, of course, unique to the Dutch East Indies and the 19th century saw the management of bodily functions become an increasing focus of Europe's growing civilising mission and, by the early $20^{\text {th }}$ century, racialised medicine was a tool of Empire (Amrith 2006; Anderson 2006; Boomgaard 1993; Hattori 2004; 
Latour 1988). ${ }^{2}$ Writing about southern Africa, Comaroff and Comaroff (1997) highlighted the deep interaction and conflict around healing and hygiene involving missionaries, colonial authorities and local populations, which resulted in increasing policing of domestic life. In Africa and elsewhere, these interventions produced various forms of resistance that can be seen as 'emblematic of the broader cultural confrontation at work in the colonial encounter' (Comaroff and Comaroff 1997: 337). These conflicts remain in play in the postcolonial context as we see with WSP.

The Rockefeller Foundation program, with its focus on education, had more impact than Dutch programs in changing sanitary practices. The program in Indonesia, as in much of South East Asia, originated through the activities of Dr Victor Heiser, who was initially director for the East, International Health Board. ${ }^{3}$ He met resistance in establishing a program though, as Dutch officials did not think that the education and propaganda approaches used by Rockefeller would work in the Dutch East Indies. They even argued that these programs might disrupt authentic customs and traditions of Java's villages (Gouda 2009). ${ }^{4}$

The program in Indonesia was run by another American, Dr John Lee Hydrick, who was in Java between 1924 and 1939 tasked with applying the Foundation’s successful US hookworm prevention model (Hull 2008: 140; Hydrick 1942). Hydrick established a demonstration project in Bantam, an area West of Java, using the Foundation's education-based model, while the government's Public Health Service set up another using the traditional authoritarian Dutch approach, in this case involving provision of worm medication and 'mandatory enforcement of regulations to build

\footnotetext{
${ }^{2}$ The civilising mission in colonies was, in many ways, a continuation of the moral crusade in the Victorian era regarding the conditions of the urban poor, which also prompted often coercive public health interventions (Black and Fawcett 2008: 21-2) As Latour explains, the expansion of public health measures was also a contested process in Europe. It only became dominant (or rather hegemonic in the Gramscian sense), after Louis Pasteur's ideas became mainstream amongst the physicians, which took some 40 years (Latour 1988: 136-40). However, once it had obtained this dominance, hygiene equally turned to 'policing and coercion' (Latour 1988: 140).

${ }^{3}$ The International Health Board (initially Commission) was established in 1913 with a grant from the Rockefeller Foundation. It was inspired by the work of the Rockefeller Sanitary Commission for Eradication of Hookworm Disease and worked with it (Rockefeller Foundation). This latter program worked initially with African-American communities in the southern US before turning its sights globally - to Egypt, the north of Australia, the Philippines and elsewhere (Anderson 2006). The Philippines was the Rockefeller Foundation 'test bed for many of its international health projects, whether in racial development (as in hookworm prevention) or ecological intervention (as in malaria control)' (Anderson 2006: 217). ${ }^{4}$ Other factors were undoubtedly Dutch concern about growing US influence in the region after their takeover of the Philippines in 1901 (Gouda 2009) and specific rivalry between Rockefeller's Standard Oil Co. and the Dutch petroleum industry (Hull 2008: 141; Mesters 1996: 56-7). The US were pioneers in providing colonial public health programs and spent significant sums on the effort in contrast to the Netherlands East Indies where colonial welfare was self-funded and always a clear second to Dutch financial interests (Zainu'ddin 1968: 156). The US did, however, also adopt a range of quite coercive techniques including in the sanitation campaign, where the Rockefeller Foundation was also a key player, for details see Anderson (2006). The US public health program in Guam was perhaps even more authoritarian given it was run by the US military, see Hattori (2004).
} 
latrines' (Hull 2008: 142). This competition was driven by the colonial administration's desire for Rockefeller funding without their staff and programs. Nevertheless, the comparison of the two approaches in early 1926 showed that, while the Dutch program had resulted in the construction of some 150,000 latrines, few if any were in use; the Rockefeller program produced fewer latrines but they were in use and the population seemed enthusiastic about the program (Hull 2008). Subsequent research has questioned the enthusiasm, a topic we return to a little later in the paper (Stein 2006). As a consequence a new Public Health Education unit was set up with a Hygiene Propaganda Unit using mass media and education to promote preventative health techniques, with funding coming from the Rockefeller Foundation, the colonial administration and local governments.

It is interesting to note that Hydrick's enthusiasm for educative techniques was not a social or moral issue but one of efficiency. His 1942 booklet on the program provided a mix of arguments to support education, starting with the analysis that attempts 'to carry out hygienic measures by beginning with the use of force gives rise to active and passive resistance which always accompany the enforcement of any law which is not supported by public opinion' (Hydrick 1942: 18, emphasis in original). Hydrick (1942: 18) argued that education may require 'great patience and devotion' but it produces permanent results, with the proviso that laws and regulations may be needed once overall public opinion supports new system for the remaining few 'reactionary individuals'. His support for education was limited to rural areas where distances mean enforcement would require too many personnel, whereas in urban areas Hydrick saw that 'it is often necessary to use force' (Hydrick 1942: 19, emphasis in original). Indeed, he (1942: 19-20, emphasis in original) had 'no objection whatever to the use of coercion if its use could secure permanent results.'

The program itself saw health workers (mantri) recruited to conduct the education component. They were initially all male and had to be literate, not too young or old and have a good speaking voice. They received intensive field training prior to commencing their duties, which initially focused on hygiene and hookworm but were expanded over time (Hull 2008: 146; Hydrick 1942: 66-8). There was also a mass media component that produced popular silent films for the annual fairs in towns. While Hydrick (1942: 35) was not convinced of the film’s efficacy in changing hygiene habits, Stein's (2006) deconstruction of them, showing how they assumed their audience was scientifically and cinematically illiterate, is the more important issue for this analysis. Thus, for example, the process of magnification was thought too complex for villagers to understand so several films spent much time elaborating on the process (Stein 2006: 27-8). Further, while one of the hookworm films was not overly moralising, most used quite explicit and 'disgusting' images of villagers holding pans of worm expelled from their bodies. As Stein (2006: 27) concludes, this image: 'signifies the truth of the diseased Javanese body and aimed to turn audience disgust inward, toward the wormy 
self.' Thus there was in this, as in most of the Rockefeller health efforts, strong racist overtones (Anderson 2006).

Hydrick (1942: 73) prioritised cost and education over construction standards: '[t]he latrine should cost very little or nothing, but if possible it should be durable, convenient and sanitary.' To this end, the program allowed that initially a latrine needed be little more than a hole:

covered with a strong bamboo frame which is in turn covered with a bamboo mat to shut out the light. The small hole in the center is kept closed by a piece of wood or woven bamboo which serves as a cover. This type costs the village man nothing... Later after he has learned to use a latrine, he is willing to spend something for better materials... (Hydrick 1942: 73).

It is more important that the people learn to use a latrine and thereby stop the general pollution of soil and water. Also the people must first learn to use a latrine and to keep it sanitary. After this habit has been thoroughly implanted, then the question of improvement of type and material can be taken up (Hydrick 1942: 75).

Despite some claims of success for the Public Health Education unit (Hull 2008: 146) and the low cost focus, Stein (2006: 38) found that many people in Hydrick's demonstration area did not build latrines and that locals remembered the project as being for the wealthy. Even local materials came at a cost and it took up to a week's labour to construct the latrines - a process which had to be repeated every few years. This involved significant costs, especially in the 1930s when Java was deeply impacted by both the Great Depression and local economic crises and many villagers were focused on little more than survival. Nevertheless, Hydrick was strongly opposed to latrine construction or subsidisation by colonial authorities or donors - another debate which rages to this day. The WSP sides strongly with Hydrick here, indeed WSP could have borrowed verbatim Hydrick's (1942: 74) comment that '[e]xperience has already shown that the people are willing to build latrines if they can be shown how this can be done without great costs. ${ }^{5}$

By 1932, the Dutch had come to accept that there was a need for a broader range of health services constantly accessible by locals and a decentralised approach to delivery was thought appropriate (Hull 2008; Mesters 1996). Such interventions were seen as a counter to the growing unrest in

\footnotetext{
${ }^{5}$ Hydrick's views on the funding of medicine and hygiene were a small advance on the common colonial position, namely that medical care is an individual responsibility other than in the case of epidemics and emergencies and that government's role should be limited to basic infrastructure provisions (Abeyasekere 1986: 2-3). This minimal view of the government's role in health returned with the neoliberal revolution in the 1980s and it, along with the neoliberal view of utilities, influenced donor ideas about how sanitation programs should run.
} 
Indonesia, though the depression of the 1930s meant that there was little funding for programs (Amrith, 2006: 30). So Hydrick was given the job of developing health units, which are the basis of the system of health clinics that continued into Suharto era (Stein 2006: 20).

Hydrick departed the East Indies in mid-1939, he had a long career with the International Health Board in a range of former or current colonies, which as Anderson (2006: 229-33) has shown, was during the 1920s and 1930s, critical to the creation of a complex circulation of health staff across the Pacific and Western Hemisphere. This is important because both the programs studied here need to be situated within a framework emphasising the international and transnational circulation of governmental technologies in health. With regards to the Rockefeller program, Amrith (2006: 32) notes:

Through the League of Nations, the Rockefeller Foundation and other transnational networks, the local techniques of Hydrick and his counterparts across the region began to coalesce into a set of ideas and prescriptions gaining ethical force, as a body of knowledge and practice: 'international public health'.

Further, Amrith (2006: 11) emphasises how the creation of international health organisations bolstered the governmentalism of colonial and postcolonial health programs and states. ${ }^{6}$

Hydrick and the Rockefeller Foundation did not succeed in fully changing the Dutch approach to colonial sanitation and health practices (Mesters 1996: 60-1). As late as 1945, Dr P. Perverelli former director of the Dutch East Indies Public Health Service claimed that modern medicine 'should simply be imposed, either through courteous coercion (printah haloes) or more forceful measures' (cited in Gouda 2009: 2-3). The Dutch responses to malaria, the plague and smallpox all showed that coercive techniques remained central. The smallpox program's coercive techniques prompted locals to flee to mountains and the Plague Service in the $20^{\text {th }}$ century was renowned for spleen punctures (which violated Muslim beliefs about not violating the body after death), costly compulsory rat-proofing programs for houses and even burning down whole villages touched by plague (Abeyasekere 1986: 10; Boomgaard 1993: 87).7 Thus there is a complex overall picture, on the one hand, as Stein (2006: 39) concluded, the hygiene projects do represent a move away from

\footnotetext{
${ }^{6}$ Though as Amrith (2006: 11) argues colonial and post-colonial health was as much characterised by its absence, ineffectiveness and failures and there is a tension between this view and one which emphasises governmentality.

${ }^{7}$ Further the health budget remained dominated by a small curative and technical program (Abeyasekere 1986: 4-5). After independence, the relative funding of curative over preventative services continued, though the Dutch system of rural polyclinics was dramatically expanded to a network of Primary Health Care centres.
} 
the most dominative colonial health and village control practices. Further, they were an early step beyond the minimalistic colonial health model of "preventing epidemics and ensuring the productivity of labour” (Amrith, 2006: 2) though hookworm treatment was strongly motived by labour productivity concerns (Anderson 2006; Hattori 2004). On the other hand, the Public Health Service established by Hydrick and the Dutch went beyond this concern, it used education as well as some coercion and expanded the state's regulation of colonial subjects. In other words, the programs embody a shift towards rule though governmentality that occurred in the late colonial period though there was 'a degree of intrusiveness unforeseen even by Foucault and others in their theorizations of state intervention and surveillance' (Hattori 2004: 180). Further, the racialised overtones of earlier public health interventions remained.

\section{THE WORLD BANK WATER AND SANITATION PROGRAM}

Despite the work of the Rockefeller Foundation and others in encouraging a public health focus in hygiene and health care, in the three decades following World War II the focus of sanitation projects in developing countries was largely hardware and engineering. Indeed, donors in general did not focus much on sanitation - it was, and remains, the poor relation to water supply (Black and Fawcett 2008: 40; WaterAid 2011). ${ }^{8}$ The big reductions in mortality in this period were not due to success with diseases related to standards of living (Amrith 2006: 184). By the mid-1960s, “"nonspecific" diarrhoeal diseases were the biggest killers in Asia and Africa' and '[ $t$ ]hese "non-specific" infections proved much less amenable to control with technological "magic bullets"' (Amrith 2006: 184).

The focus on hardware in sanitation started to change in the late 1970s, which was when the Water and Sanitation Program was established. It started in 1978 with a focus on testing low cost technologies and models for providing safe water and sanitation to the poor. This was following the 1977 UN Conference on Water, after which the World Bank downgraded its support for sites and services interventions, seeing in the newly discovered resourcefulness of urban slum dwellers a reason to withdraw direct financial support and provide assistance only for technology and models (Black and Fawcett 2008: 41-2). Rural inhabitants were not regarded as resourceful, so the limited number of rural projects focused mostly on latrine construction and continued with the inadequate attention to education resulting in many unused latrines (Black and Fawcett 2008: 41-2, 77).

\footnotetext{
${ }^{8}$ This seems true in academia as well - for example, a search of the term 'sanitation' in the journal Development and Change did not uncover any article focused predominately on sanitation.
} 
In the 1990s, the Bank's new approach to sanitation was reinforced by the replacement of 'supplyside thinking' with a focus on local communities accessing 'water and sanitation services according to their own demands' (WSP 2011). In other words, the neoliberal revolution and the associated structural adjustment approaches that the Bank applied to public utilities in the 1980s furthered the hostility to state provision of sanitation and water services (Amenga-Etego and Grusky 2005; Engel 2010; Yi-chong 2005). At the grassroots level, this was presented as a shift to demand responsive approaches which encouraged the poor to 'take responsibility' for their own development and, of course, pay for it. So WSP now offers a combination of self-help water and sanitation programs and evaluation and research to expand knowledge. ${ }^{9}$ It also continues to promote expanded private sector participation in these sectors, which was another key battleground of the 1990s.

Self-help approaches have been particularly appealing in the troubling and expensive area of sanitation where a lack of funds, management skills, maintenance capacity and water supply have all meant that the water-borne sewerage disposal and treatment model prevalent in the industrialised world is rarely viable in urban settings and is regarded as irrelevant in rural ones (Black and Fawcett 2008: 7). The change in thinking about sanitation did see the re-emergence of useful insights about the importance of education and mobilisation that were known to the Rockefeller Foundation and Hydrick 60 years earlier. That is to say that when latrine construction is imposed by coercion or decree, it usually fails, people must want and value latrines for them to be used and maintained (Black and Fawcett 2008; Jewitt 2011) Equally, though sanitations programs need more than just education according to a donor program, they need to understand and engage with local practices impacting sanitation and local practices regarding excrement disposal; they need to study what works in creating and maintaining demand for sanitation in an area and what of types sanitation a community prefers, otherwise sanitation systems tend not to be used (Black and Fawcett 2008; Jewitt 2011). Furthermore, WSP's strong focus on community led and controlled projects does not fit with historical experience regarding broad access, which show that without government intervention, services have only been provided in wealthier locales. ${ }^{10}$ The issue of access by the poorest is only now gaining increased focus in CLTS processes (Fawazi and Jones

\footnotetext{
${ }^{9}$ In addition to the World Bank's lead role in WSP, it is a significant player in the sector through its lending program. Its International Development Association lending arm is the second largest provider of official development assistance (ODA) to the sector after Japan (WaterAid 2011: 29). The International Bank for Reconstruction and Development arm of the Bank is also a significant lender in the sector.

${ }^{10}$ Successful systems see government play a central long-term role in investment in 'public health institutions, governance and regulation, marketing, technology, R\&D, and other underpinning components of a new sanitary order' (Black and Fawcett 2008: 193-5). Further, successful sanitation systems have always involved both public and private components (Black and Fawcett 2008: 51). The private sector has generally been central to ensuring the supply of appealing items at affordable prices in locations people can access and they have played a role in maintenance and repair of systems too.
} 
2010; WaterAid 2011), undoubtedly because WSP’s key focus has been discouraging subsidies for latrine construction in any context.

\section{Sanitation and Shaming: WSP in Indonesia}

The sanitation situation overall in Indonesia is poor - it has the third highest number of people of any country in the world without access to sanitation, over 109 million people in 2010 (WaterAid 2011: 17). This is despite slow improvements in the past couple of decades - in 2008, 67 per cent of urban dwellers and 36 per cent of rural dwellers used improved sanitation facilities, up from 58 and 22 per cent in 1990 (WHO / UNICEF Joint Monitoring Programme for Water Supply and Sanitation 2010: 11-2). ${ }^{11}$ In rural areas, 30 to 40 per cent of the population still engage in open defecation. This situation reflects in many ways the general lack of focus on public health care during the Suharto years, which resulted in poor health outcomes by regional standards despite achievements in economic growth and poverty reduction (Achmad 1999). Suharto's interested in health only extended as far as family planning. Given the strong influence of the paternalistic central government priorities, which continued the late colonial tendency to village political demobilisation and the "weak grass-roots demand for political participation and social services", public health languished (Achmad 1999: 1).

The process of decentralisation that commenced in 2001 saw districts government given responsibility for water supply and sanitation. It has not yet resulted in notable improvements in access or service quality, which has been generally attributed to lack of resources and capacity in district governments. Indonesia has seen some donor activity in the sanitation or water sector between 2002 and 2009 official development assistance disbursements to the water supply and sanitation sector grew from USD \$30 million to \$155 million per annum and the largest donor was the World Bank's IDA, followed at some distance by Japan and the Netherlands (OECD 2011). The World Bank’s direct lending for rural water supply and sanitation sector work has mostly been through its Water and Sanitation for Low-Income Communities (WSLIC) program as well as technical support through the WSP. ${ }^{12}$

\footnotetext{
${ }^{11}$ But only two per cent of urban dweller's sanitation systems connect to piped sewers and these are nonexistent outside urban areas.

12 The third stage of the WSLIC was renamed PAMSIMAS for its Indonesia title - Program Penyediaan Air Minum dan Sanitasi Berbasis Masyarakat (Community-Based Drinking Water and Sanitation Provision Program). The World Bank also offered support to the water supply and sanitation sector through its large rural community development programs (KDP and PNPM), where villages can select from a menu of
} 
The WSP started promoting the CLTS process as early as 2001 and was instrumental in its spread to other developing countries including to Indonesia in 2004 (Buhl-Nielsen, Giltner et al. 2009; Kar and Pasteur 2005: 6-7). Indonesia was also one of three participants in the WSP's Global Scaling Up Rural Sanitation launched in 2006 (Cameron and Shah 2010: v).$^{13}$ The project was focused on 29 Kabupaten (regencies or cities) in East Java and it aims to end open defecation using the CLTS process. Open defecation is a major health and sanitation issue across densely populated East Java as approximately 40 per cent of households still practice it. ${ }^{14}$

We studied the WSP in East Java generally and specifically in Kabupaten (district) Trenggalek. For East Java overall, we analysed WSP documents, reports from independent evaluations and interviewed regional officials. A further key informant was a researcher working for the Jawa Pos Institute of Pro-Autonomy (JPIP) - a local foundation of East Java's largest media network that has been tasked with monitoring the implementation of WSP. In Trenggalek, we undertook an initial series of interviews in 2010 with different stakeholders including heads of the villages (Kepala Desa), local government officials and local WSP facilitators. In this round, we conducted formal interviews with nine people and the interviews with village residents were conducted in the presence of local government officials. In 2012, we undertook further interviews with seven households without government officials present. We do not claim thus, that this is a comprehensive view of the WSP in East Java, though the qualitative focus provides strong insight into a range of key sanitation issues.

For the East Java program overall, the facilitators are trained by WSP for participatory analysis of existing community sanitation practices and how they could be improved. Most WSP funds are spent on technical assistance, including regular training and workshops mostly for facilitators as well as for government officials. Each district cannot receive more than IDR 40 million (approximately US \$4,500) per year of WSP funds and, in addition, local governments contribute towards project costs (Jawa Pos Institute of Pro-Otonomi 2009: 15). To support the program, facilitators are recruited and trained by WSP Jakarta to work in the national office (Jakarta-based) and in local offices (district based). The national office trained facilitators in Jakarta are paid by

infrastructure and social sector improvements, however, communities have only used five per cent of funds for improving sanitation facilities (Buhl-Nielsen, Giltner et al. 2009: 5).

${ }^{13}$ The other countries are India and Tanzania. In Indonesia, this project is known as Sanitasi Total dan Permasaran Sanitasi (SToPs).

${ }^{14}$ Those who do have access to sanitation facilities either have access to a septic tank (36 per cent), various forms of pit latrines (16.3 per cent) or a piped sewer system (around 7 per cent) (Cameron and Shah 2010: 26). 
WSP, whereas local facilitators are paid by from the local government. ${ }^{15}$ This strong link to local government is an interesting divergence from the standard CLTS model where facilitators are engaged by NGOs.

Some IDR 20-25 million was allocated in 2008 for sanitation training in East Java. The training was held in Surabaya (the capital of East Java Province) and hundreds of participants attended.

Participants learnt techniques for working with communities and training on sanitation issues. They were also taught technical skills for constructing a toilet. Of the 37 districts in East Java, 29 have implemented the WSP. In interviews with staff from Badan Pemberdayaan Masyarakat (Department of People’s Empowerment) in Kabupaten Trenggalek (June 2010), they indicated that regions were selected based on the following criteria: (a) the location is far from a river or canal; (b) there is high participation by villagers (civil society); (c) the village is not classified as poor; and (d) there are active and/or participative stakeholders. As to why villages could not be poor, the response from staff was that this was the guidelines they were given. This is a powerful statement of the lack of poverty focus in WSP.

There are strong parallels between WSP's facilitation and Rockefeller's education process. In both cases, the aims and objectives of the education/facilitation process were determined from the outset by donors and experience in other countries, not by local communities and both show the logic of governmentality in how they identify what and who is the problem and how they respond, using a staged response of special techniques and specially development promotional and educative materials. Both programs target communities and households as the site of their intervention; however the Rockefeller program had a stronger focus on households than WSP. Indeed, the Rockefeller program demonstrated greater concern about the dignity of households, working with them one-on-one to ensure privacy and open discussion (Hydrick 1942: 30-1).

\section{Trenggalek}

Kabupaten Trenggalek is located in southern part of East Java province and, due to a large mountain range, it is relatively isolated area, yet like most of Java it is quite densely populated. Trenggalek district has been a leader in sanitation - in 2008, it had the second highest budget for sanitation of any district in East Java and made a commitment to being free of open defecation by

\footnotetext{
${ }^{15}$ Specifically through the Anggaran Pendapatan dan Belanja Daerah (APBD).
} 
2010 (Jawa Pos Institute of Pro-Otonomi 2009: 15, 25). ${ }^{16}$ In addition to examining the overall WSP process in Trenggalek, we undertook interviews in two villages, Rejowinangun in Kecamatan (subdistrict) Trenggalek and Panggungsari in Kecamatan Durenan, in order to develop a deeper understanding of how WSP has impacted residents. The villages were recommended by staff from the Department of Health as the villages in Trenggalek that has most quickly obtained Open Defecation Free (ODF) status. In both villages many of the younger villagers have gone to larger towns or overseas (Malaysia and Hong Kong) for work (as Tenaga Kerja Indonesia (TKI) /Indonesian Labour Force). A key reason that WSP was implemented in both villagers is because many households were still using the canal and river for defecation and waste disposal, thus the criteria of being far from a river seems to have been reversed here.

The WSP/CLTS facilitators in both Rejowinangun and Panggungsari was a government official from the local health centres - in Indonesian, Pusat Kesehatan Masyarakat but generally known by the abbreviation PUSKESMAS. This is a major departure from the original CLTS model, where the facilitator is generally an outsider and the process of looking at village 'filth and dirt' though an outsiders eyes is regarded as a key factor in initiating change (Kar 2003: 27). As per the model, WSP encouraged the construction of individual latrines and shared public toilets, which can be traditional, semi-permanent or permanent. The type of toilet to be constructed depends on the capacity of the families using it to pay for its construction. The poor are encouraged to form a group of three or four families to erect one shared traditional public toilet, which is accessible to all of them. Semi-permanent and permanent public toilets are shared amongst low and middle income families. A shared traditional pit latrine can cost as little as IDR 25000 though our studies found most cost IDR 200 000. A semi-permanent latrine costs around IDR 500000 while a permanent indoor pour-flush toilet costs around IDR 1000000 per unit, in other words, between approximately US \$2.75 for a traditional pit latrine and \$50- \$100 for more permanent and pleasant sanitation facilities. In theory, WSP in Indonesia provides no subsidies for toilet construction yet in practice we found both rewards and provision of pit rings and covers from the village head.

Nevertheless, the outlays required from households were quite large given 32.5 per cent of the Indonesian population live below the (quite low) national poverty line of US \$21 per month and a further 40 per cent live just above it (World Bank 2010).

Indeed, there is growing evidence that WSP is not accessing the poorest (Fawazi and Jones 2010) and that subsidies have beneficial impacts in particular circumstances and are being supported by some governments, for example India (Black and Fawcett 2008; McFarlane 2008; Pattanayak, Yang

${ }^{16}$ Kabupaten Trenggalek came seventh out of 29 in JPIP's 2009 award for best practices in sanitation in East Java. 
et al. 2009). ${ }^{17}$ In our second round of interviews which were in Rejowinangun, six of the seven households we interviewed had constructed latrines - one household could not afford the additional cash outlay required for construction despite having received a concrete pit liner and cover from the village chief. Two other households also received concrete pit liners, despite the CLTS opposition to subsidies and support for using local materials for construction. For five of the six households where latrines were constructed, the costs ranged between IDR 200000 and one million depending on the type of latrine constructed. Further, in five household there was a loss of between three days and two weeks income due to time spent in labour and supervision of latrine construction. All of the households noted that this was a drain on their income. Despite these realities, the World Bank is reporting the outcomes of WSP to the Joint Monitoring Program on progress towards the MDGs for sanitation and they do not consider the impact that the cost the progress in sanitation may have on the capacity of the poor to meet other MDGs (Mukherjee, Wartono et al. 2010: 1).

Both villages supposedly followed the standard CLTS process - to foster improvements in sanitary standards, it used a triggering method involving approaches and informal talks with stakeholders prior to the project being formally triggered. Local facilitators (called cadres) were responsible for organizing triggering, the first stage of which involved cadres disseminating information on health and sanitation to villagers both door-to-door and through public meetings (musyawarah desa). ${ }^{18}$ The meetings took villages through the standard CLTS process of a walk of shame and defecation mapping - all of which aimed to trigger subsequent latrine construction. The first three months was considered the hardest period in triggering, but after a further five months, officials claimed that 97\% of total population in the villages had access to at least a public toilet. ${ }^{19}$ However, in our first round of interviews, the Kepala Desa (village head) in Panggungsari stated that villagers were not intensively engaged during the early phases of the CLTS, rather the importance of this project was taken for granted by the Kecamatan. He said that many villagers did not even know that their village was being used as a trial for the CLTS process. The situation was similar in Rejowinangun, where in our second round of interviews we found that one of the two hamlets in the village had in fact, not fully, participated in WSP and, of the seven households we spoke to, two had never heard

\footnotetext{
${ }^{17}$ Studying a urban sanitation project in India using a similar participatory process, McFarlane (2008: 102) notes that the 'focus on cost recovery from the poor means that sanitation is often provided not according to those who need it most, but according to how many can pay a contribution.'

${ }^{18}$ In Rejowinangun as in other areas in Indonesia, religion has been used in promoting cleanliness, thus reciting the Koran (pengajian) was also a tool for disseminating information.

${ }^{19}$ CLTS also promotes strong public displays of commitment, in Rejowinangun this took the form of villagers sticking pamphlets on the sides of their toilet walls stating: 'we commit to not using the river for waste anymore' (Kami tidak akan buang air lagi di sungai).
} 
of WSP and a further three said they had heard of the program but had not been involved in the participatory and socialisation components.

According to the Kepala Desa in Panggungsari, despite the supposedly participative approach of the CLTS, the villagers did not want a sanitation project and preferred an adequate irrigation system for their farm land and a program for re-planting the cleared forest located near their farm land. The deforestation occurred in 2001, when a group of people from another are came and cut the trees for logging. The logging caused a large area of land to become infertile. ${ }^{20} \mathrm{~A}$ further indication of the lack of community participation comes from the Jawa Pos Institute of Pro-Autonomy (JPIP) public survey across East Java in 2009, which showed that 58.7 per cent of respondents thought that the key factor in the success of sanitation improvement programs was the level of commitment of the district head, whereas community participation was seen as key by only 6.6 per cent. They note that: 'This is an ironic finding as sanitation improvement programs have been claimed to involve more community roles' (Jawa Pos Institute of Pro-Otonomi 2009: 13). Yet, there is little doubt that government support is vital in achieving ongoing improvements in sanitation and the lack of commitment has been noted as a key reason for Indonesia’s poor progress until the last few years. Indeed, there was a dramatic change in the commitment to WSP in Trenggalek after the election of a new Bupati (Mayor) in 2011. WSP is not his priority; rather he has a strong focus on waste management so by late 2011 the project was no longer active. Sanitation cadres were, in 2011, still assisting people with latrine construction but enthusiasm for achieving open defecation free status (ODF) has declined. A very active WSP cadre, who we interviewed in October 2011, has been told that he will be transferred to another post in different department by the end of the year. He noted that there were no cadres to replace him.

According to this WSP cadre, one of the reasons for the enthusiasm in Trenggalek for the project was that the previous Bupati promised a reward of IDR 5 million (US \$555) per village for Open Defecation Free (ODF) certification. The cadre felt that the reward stimulated people to construct a toilet even though the price was not always within their means partly because of community pressure to get the reward and partly because it was felt that the reward would be used to repay the debt. However, the complication of both the reward and the use of shaming techniques, means that we think it is difficult to judge the motivations in such instances. The 'reward' and the provision of

\footnotetext{
${ }^{20}$ The villages linked the soil infertility and deforestation to water shortages, however, the exact causality is unknown.
} 
concrete pit liners and covers in some places in Trenggalek can be viewed as a local way of getting around WSP's hostility to subsidies. ${ }^{21}$

The CLTS model used in Trenggalek, as elsewhere in Indonesia, relies strongly on techniques involving shame, enforcement, responsibility and sanctions. Each villager has to take responsibility for analysing the extent of open defecation, for financially and morally solving the problem and for reporting to local and district government - in a participatory manner of course (Mukherjee, Wartono et al. 2010: 2). In some communities, those households with unimproved sanitation are marked with a sticker, 'which serves both as an embarrassing and persuasive force encouraging owners to upgrade to improved facilities as soon as possible' (Mukherjee, Wartono et al. 2010: 9). ${ }^{22}$ In two villages elsewhere in East Java, regulations providing sanctions for open defecators were instituted - the sanctions involved offenders sweeping village offices and fines. One village used village funds to take and post pictures of open defecators. These fines and public humiliation were reported by the JPIP as ‘distinguished institutionalisation’ (Jawa Pos Institute of Pro-Otonomi 2009: 12)! The JPIP awards were supported by WSP (Mukherjee, Wartono et al. 2010: 17).

The WSP has also produced its own social marketing material staring a figure called Lik Telek, which translates roughly as Uncle Faeces (Water and Sanitation Program World Bank 2008). Lik Telek is poor, physically deformed, dirty and 'disgusting', he is quite similar to a character called Kromo in one of the films produced by the Rockefeller program in Indonesia (Stein 2006). Interestingly, Kromo is, in some ways, not as caricatured as Lik Telek, Kromo’s name is a colonial Malay word for 'common people' and he is disfigured but not as dirty or perverted as Lik Telek, who in one image is presented as a peeping tom. Indeed, as Stein (2006: 24) points out, the film about Kromo is designed more to elicit 'empathy and identification from the audience' than it is to encourage moralising, though other films produced by the unit did adopt a more moralising tone highlighting the underlying belief in the diseased Javanese body. One of our informants from the 2012 interviews in Rejowinangun shared that he had been identified as a Lik Telek. He said it was 'very embarrassing' to be Lik Telek and that the village head and other government staff had 'encouraged' him to construct a latrine by teasing him and his family because of their use of the canal. He said the 'Village Head and his staff teased me like this: 'you have a gorgeous wife, if you

\footnotetext{
${ }^{21}$ A number of CLTS supporters have expressed concern about the negative impacts of offering inappropriate (or indeed any) incentives to achieve ODF status (Harvey 2011; Kar and Pasteur 2005: 4). The experience in Trenggalek indicates that it changes the process as was the case in Noy and Kelly's (2009) study of East Timor where the 'reward' for achieved ODF status was transition to a water supply program. ${ }^{22}$ Moreover, to be certified as ODF, whole teams visit specified households and guideline 1.3 for verifying villages as ODF, states there must be: 'sanctions, rules or other safeguards imposed by the community to prevent open defecation' (Mukherjee, Wartono et al. 2010: 22).
} 
are not making a proper toilet, we may see your wife”,' The 'encouragement' did not seem to consider his poor household circumstances at the time though he was given a concrete pit liner by the village head for his latrine.

The Chief of WASHE for UNICEF, Peter Harvey, has claimed that while shock factor is part of CLTS, the triggering process done by external facilitators should not 'shame, insult or embarrass the community in anyway’ (Harvey 2011: 100). Yet CLTS is clearly a very intrusive process involving facilitators from outside the village inspecting individual households and shaming predominately poor individuals and households for their circumstances and local practices. The process has, since its inception in Bangladesh, involved a policing and punishment component. ${ }^{23}$ In both WSP and the Rockefeller project, such interventions seem to take place within a village realm that is seemingly free of differences - there are no class, ethnicity, gender or age distinctions. Thus, the possibility that the projects will adversely impact any particular group is not considered, indeed with WSP the implicit assumption is that the participatory CLTS process will reconcile these sometimes antagonistic interests (Carroll 2010: 4; Zérah 2009). Our research indicates that it is predominately the poor who are the 'targets' of this 'intervention' and that they are, in effect, punished for their poverty and local practices.

Sustained latrine use is meant to be a further strength of WSP as it was for the Rockefeller program. However, evidence for this is slim. For WSP, despite the claims of its efficacy there is, in fact, still very limited data on outcomes for latrine use across the globe. ${ }^{24}$ One study in Timor Leste found that regular latrine usage may have only been 50 per cent one year after the program (Noy and Kelly 2009) and a study of CLTS in Indonesia found only 12 per cent of 547 participating villages had achieved ODF status (Buhl-Nielsen, Giltner et al. 2009). Our interviews in 2012 in seven households, showed that one latrine was already full and the household had returned to open defecation and one latrine was close to being full. While the family was willing to have the pit emptied, they did not have sufficient funds to do this and were not sure when they would. Further, one of the latrines that was designed to be used by three households was only being used by the one

\footnotetext{
${ }^{23} \operatorname{Kar}$ (2003: 40) explains in Bangladesh:

The communities also developed innovative community policing and sanctioning methodologies. They undertook collective action, started night patrols to catch offenders that still used open spaces, undertook early morning raids on defection spots and used the village watchmen to catch and identify offenders. This policing procedure in itself became a community project and fines were imposed on the offenders while financial rewards were offered to the identifier and the witness. Money from the fines supported the WATSAN committees. Even children participated in the project by following offenders and then sticking little name flags on the "offence" so that passers-by could identify the guilty party. ${ }^{24}$ A study by CLTS founder Kar and Shafi found most latrines were in Bangladesh were in use and being maintained (cited in Kar and Pasteur 2005: 3).
} 
household we spoke to as the latrine was on their property. They said that the other households do not use the latrine because they are concerned about disturbing the household whose land it is on and that, if all the households used the pit, it will get full too quickly and require emptying. Thus we consider that the effectiveness of CLTS in providing long-term sustainable sanitation solutions is questionable and certainly requires further research.

\section{CONCLUSION: SHAMING AS NOT SO PARTICIPATORY DEVELOPMENT}

In this paper, we examined how WSP involves a process of governmentality that is more than reminiscent of colonial government programs constructing sanitation practices not conforming to (newly discovered) Western standards, as filthy and backwards. The result is that sanitation programs do not tend to engage with local practices in their cultural, social, political and economic dimensions. A better appreciation of pre-existing local sanitation practices as well as related spatial, economic, cultural and psychological factors is more likely to produce inclusive, holistic local sanitation systems that do not rely for their success on humiliating people. ${ }^{25}$

In Indonesia, there has been no analysis of the deeper cultural and social norms around sanitation and very little about the political, spatial and economic dimensions. These are important aspects if participatory development schemes are to work in sanitation and to get beyond derogatory, shaming approaches. The CLTS/WSP program combines ideas from grassroots empowerment and neoliberal self-help doctrine. However, the use of shaming and taunting both disqualifies it as an empowerment approach and is likely to undermine its effectiveness in promoting long-term behaviour change. Even if shaming were shown to be effective, the morality of punishing the poor for their circumstances requires deeper consideration.

Moreover, in the hands of big donors it has become another one-size-fits-all approach to a development 'problem' intended to be scaled up and applied across globe - it was in other words, quickly rendered technical by big donors despite the calls of its founder, Kar. ${ }^{26}$ The WSP is another

\footnotetext{
${ }^{25}$ As McFarlane (2008: 97) notes the links between : '[a]ttention to the power relations within communities, and a more detailed understanding of people's sanitation needs and desires, is important if sanitation delivery is to be participatory in practice' (see also Jewitt 2011; Mukhopadhyay 2006).

${ }^{26}$ It is interesting to note the tension in Kar and Pasteur's work between commitment to the principles of the CLTS versus a concern about standardisation of the model and adapting to local conditions. Regarding standardisation, the concern is that CLTS will be reduced to a one-size fits all model by donors 'driven by targets and disbursements' (Kar and Pasteur 2005: 13). On local conditions, they (2005: 11) note that it is important to examine lessons 'from different socio-cultural, physical and political contexts'. However, overall they argue strongly for following Kar's CLTS model - the commitment to no subsidies is not
} 
example of the World Bank’s instrumentalist use of participatory rhetoric to support development programs that are fundamentally in line with the neoliberal approach of making the poor responsible for their own development (Cammack 2003; Engel 2010; Kapoor 2005; Li 2007). This is clear in the way that, in WSP, communities determining their own standards does not mean they can determine the participatory process, community priorities or redistributive mechanisms, rather it means they can select from a menu of latrine designs and police their neighbours sanitation habits. This is what passes for empowerment for Indonesian households in the post-Washington Consensus era.

debatable nor is the use of the 'pure' CLTS process. Indeed, they worry that institutional differences have emerged, which will undermine CLTS (Kar and Pasteur 2005: 3-4). 


\section{REFERENCES}

Abeyasekere, S. (1986). 'Health as a Nationalist Issue in Colonial Indonesia', in D. P. Chandler and M. C. Ricklefs (eds) Nineteenth and Twentieth Century Indonesia: Essays in Honour of Professor J.D. Legge, pp. 1-13. Clayton: Centre of Southeast Asian Studies, Monash University.

Achmad, J. (1999). Hollow Development: The Politics of Health in Soeharto's Indonesia. Canberra: Demography Program Australian National University.

Amenga-Etego, R. N. and S. Grusky (2005). 'The New Face of Conditionalities: The World Bank and Water Privatization in Ghana', in D. A. McDonald and G. Ruiters (eds) The Age of Commodity: Water Privatization in Southern Africa, pp. 275-92. London: Earthscan.

Amrith, S. S. (2006). Decolonizing International Health: India and Southeast Asia, 1930-65. Houndmills: Palgrave Macmillan.

Anderson, W. (2006). Colonial Pathologies: American Tropical Medicine, Race, and Hygiene in the Philippines. Durham: Duke University Press.

Black, M. and B. Fawcett (2008). The Last Taboo: Opening the Door on the Global Sanitation Crisis. London: Earthscan.

Boomgaard, P. (1993). 'The Development of Colonial Health Care in Java; An Exploratory Introduction', Bijragen tot de Taal-, Land- en Volkenkunde 149(1): 77-93.

Buhl-Nielsen, E., S. Giltner, P. Dutton, J. Donohoe, S.-E. O'Farrell and D. Setiawan (2009). 'Independent Evaluation of Australian Aid to Water Supply and Sanitation Service Delivery in East Timor and Indonesia'. Canberra, Australian Government, AusAID Office of Development Effectiveness, December. http://www.ode.ausaid.gov.au/publications/documents/aus-water-supplyand-sanitation-indonesia-working-paper.pdf (accessed October 2012).

Cameron, L. and M. Shah (2010). 'Scaling Up Rural Sanitation: Findings from the Impact Evaluation Baseline Survey in Indonesia', Water and Sanitation Program, World Bank, November. http://www.wsp.org/wsp/regions/east-asia-and-pacific (accessed December 2010).

Cammack, P. (2003). What the World Bank Means by Poverty Reduction. Paper presented at Staying Poor: Chronic Poverty and Development Policy, IDPM, University of Manchester (7-9 April). 
Carroll, T. (2010). Delusions of Development: The World Bank and the Post-Washington

Consensus in Southeast Asia. Houndmills, Basingstoke: Palgrave Macmillan.

Comaroff, J. L. and J. Comaroff (1997). Of Revelation and Revolution: Volume Two The Dialectics of Modernity on a South African Frontier. Chicago: University of Chicago Press.

Engel, S. (2010). The World Bank and the Post-Washington Consensus in Vietnam and Indonesia: Inheritance of Loss. London: Routledge.

Fawazi, A. and H. Jones (2010). 'Community-Led Total Sanitation (CLTS) for people in vulnerable situations: Identifying and supporting the most disadvantaged people in CLTS, A case study of Bangladesh'. London, WaterAid, September.

Foucault, M. (1991). 'Governmentality', in G. Burchell, C. Gordon and P. Miller (eds) The Foucault effect: studies in governmentality, pp. 87-104. London: Harvester Wheatsheaf.

Furnivall, J. S. (1967). Netherlands India: A Study of Plural Economy. Cambridge: Cambridge University Press.

Gouda, F. (2009) 'Discipline versus Gentle Persuasion in Colonial Public Health: The Rockefeller Foundation's Intensive Rural Hygiene Work in the Netherlands East Indies 1925-1940' Rockefeller Archive Center Research Reports Online. http://www.rockarch.org/publications/resrep/gouda.pdf (accessed September 2010).

Harvey, P. (2011). 'Community-led total sanitation, Zambia: Stick, carrot or balloon?', Waterlines 30(2): 95-105.

Hattori, A. P. (2004). Colonial Dis-Ease: US Navy Health Policies in and the Chamorros of Guam, 1898-1941. Honolulu: University of Hawai'i Press.

Hull, T. H. (2008). 'Conflict and collaboration in public health: the Rockefeller Foundation and the Dutch colonial government in Indonesia', in M. J. Lewis and K. L. MacPherson (eds) Public Health in Asia and the Pacific: Historical and comparative perspectives, pp. 139-52. London: Routledge.

Hydrick, J. L. (1942). Intensive Rural Hygiene Work in the Netherlands East Indies. New York: Booklets of the Netherlands Information Bureau, No. 7.

Jawa Pos Institute of Pro-Otonomi (2009). 'Accelerating the Change: Selecting Best Practices to Promote Total Sanitation and Sanitation Marketing in East Java'. Surabaya, JPIP, 24 June. 
Jewitt, S. (2011). 'Geographies of shit: Spatial and temporal variations in attitudes towards human waste', Progress in Human Geography 35(5): 608-26.

Kapoor, I. (2005). 'Participatory Development, Complicity and Desire', Third World Quarterly 26(8): 1203-20.

Kar, K. (2003). 'Subsidy or self-respect? Participatory total community sanitation in Bangladesh'. UK, Institute of Development Studies, September.

http://www.communityledtotalsanitation.org/sites/communityledtotalsanitation.org/files/wp184_0.p df (accessed December 2011).

Kar, K. and K. Pasteur (2005). 'Subsidy or self-respect? Community-Led Total Sanitation. An Update on Recent Developments'. Brighton, UK, Institue of Development Studies, November. http://www.communityledtotalsanitation.org/sites/communityledtotalsanitation.org/files/wp257_0.p df (accessed December 2011).

Latour, B. (1988). The Pasteurization of France Translated by A. Sheridan and J. Law. Cambridge: Harvard University Press.

Lemke, T. (2002). 'Foucault, Governmentality, and Critique', Rethinking Marxism: A Journal of Economics, Culture \& Society 14(3): 49-64.

Li, T. (2007). The Will to Improve: Governmentality, Development and the Practices of Politics. Durham: Duke University Press.

McFarlane, C. (2008). 'Sanitation in Mumbai's informal settlements: state, 'slum', and infrastructure', Environment and Planning 40(88-107).

Mesters, H. (1991). 'Public Health and colonial government in the Netherland Indies', in P. Boomgaard (ed) The Colonial past : Dutch sources on Indonesian history. Amsterdam :: Royal Tropical Institute.

Mesters, H. (1996). 'J.L. Hydrick in the Netherlands Indies: An American View of Dutch Public Health Policy', in P. Boomgaard, R. Sciorino and I. Smyth (eds) Health Care in Java: Past and Present, pp. 51-62. Leiden: KITLV.

Mukherjee, N., D. Wartono and A. Robiarto (2010). 'Managing the Flow of Monitoring Information to Improve Rural Sanitation in East Java', Water and Sanitation Program, World Bank, December. 
Mukhopadhyay, B. (2006). 'Crossing the Howrah Bridge: Calcutta, filth and Dwelling - Forms, Fragments and Phantasms', Theory, Culture \& Society 23(7-8): 221-41.

Noy, E. and M. Kelly (2009). CLTS: Lessons learnt from a pilot project in Timor Leste. 34th WEDC International Conference, Addis Ababa, Ethiopia, Refereed paper 146.

OECD. (2011). 'Query Wizard for International Development Statistics.' http://stats.oecd.org/qwids (accessed 9 March, 2011).

Pattanayak, S. K., J.-C. Yang, K. L. Dickinson, C. Poulos, S. R. Patil, R. K. Mallick, et al. (2009). 'Shame or subsidy revisited: social mobilization for sanitation in Orissa, India', Bulletin of the World Health Organization 87(8): 580-7.

Rockefeller Foundation. (2011). 'Moments in Time: 1913 - 1919.' http://www.rockefellerfoundation.org/who-we-are/our-history/1913-1919/ (accessed 2011, 24 November).

Stein, E. A. (2006). 'Colonial Theatres of Proof: Representation and Laughter in 1930s Rockerfeller Foundation Hygiene Cinema in Java', Health and History 8(2): 14-44.

Water and Sanitation Program World Bank (2008). 'Communication Tools: Total Sanitation and Sanitation Marketing in Indonesia', August.

http://www.wsp.org/wsp/sites/wsp.org/files/pop_up/WSP\%20Indonesia\%20Communication\%20To ols.pdf (accessed December 2012).

WaterAid (2011). 'Off-track, off-target: Why investment in water, sanitation and hygiene is not reaching those who need it most', November. www.wateraid.org/documents/Off-track-off-target.pdf (accessed 8 December 2011).

WaterAid. (n.d.). 'Sanitation.' http://www.wateraid.org/documents/sanitation.pdf (accessed 30 January, 2012).

WHO / UNICEF Joint Monitoring Programme for Water Supply and Sanitation (2010). Estimates for the use of Improved Sanitation Facilities: Indonesia.

World Bank (2010). 'Project Appraisal Document on a Proposed Loan in the Amount of US\$785.0 million to the Republic of Indonesia for the Third National Program for Community Empowerment in Rural Areas', Indonesia Sustainable Development Department, World Bank, March 4. http://www.worldbank.org/ (accessed December 2010). 
WSP. (2011). 'About.' http://www.wsp.org/wsp/about (accessed 8 December, 2011).

Yi-chong, X. (2005). 'Models, templates and currents: the World Bank and electricity reform', Review of International Political Economy 12(4): 647-73.

Zainu'ddin, A. (1968). A Short History of Indonesia. North Melbourne: Cassell Australia.

Zérah, M.-H. (2009). 'Participatory Governance in Urban Management and the Shifting Geometry of Power in Mumbai', Development and Change 40(5): 853-77. 